\title{
DAYA TERIMA ROTI TAWAR MOCAF DAN UBI JALAR PADA SANTRIWATI PESANTREN X
}

\section{THE ACCEPTANCE OF WHITE BREAD FROM MOCAF FLOUR AND SWEET POTATO FLOUR ON SANTRIWATI PESANTREN X}

\author{
Nurul Azizah Choiriyah ${ }^{1}$, Irra Chrisyanti Dewi ${ }^{1}$ \\ ${ }^{1}$ Program studi Seni Kuliner, Akademi Kuliner dan Patiseri OTTIMMO Internasional, \\ Jalan Telaga Golf TC 4 No 2-3 Citraland, Sambikerep, Surabaya, Jawa Timur \\ e_mail : nurul.azizah.choiriyah@gmail.com
}

\begin{abstract}
ABSTRAK
Tujuan penelitian ini adalah untuk mengetahui daya terima roti tawar yang dibuat dengan perbandingan tepung terigu, tepung mocaf dan tepung ubi jalar putih yang berbeda. Perlakuan tepung terigu:tepung mocaf : tepung ubi jalar putih pada penelitian ini yaitu (200:0:0) g, (160:40:0) g dan (160:0:40) g. Analisis yang dilakukan pada penelitian ini yaitu uji organoleptik menggunakan uji hedonik. Penelitian ini menggunakan Rancangan acak lengkap. Data yang diperoleh dianalisis dengan menggunakan ANOVA dengan uji lanjut DMRT pada taraf signifikansi $95 \%$. Substitusi tepung terigu menggunakan tepung mocaf dan tepung ubi jalar putih berpengaruh terhadap daya terima dengan parameter warna, aroma, rasa, dan tekstur roti tawar. Tepung mocaf berpotensi sebagai pengganti tepung terigu dalam pembuatan roti tawar dibandingkan tepung ubi jalar. Parameter rasa dan tekstur roti tawar tepung mocaf pada uji organoleptik mendapatkan penilaian suka dari panelis. Sedangkan parameter rasa dan tekstur roti tawar tepung ubi jalar pada uji organoleptik mendapatkan penilaian agak suka dari panelis.
\end{abstract}

Kata kunci : mocaf, roti, substitusi, ubi jalar, uji organoleptik

\begin{abstract}
The purpose of this study was to determine the acceptability of white bread made with a different ratio of wheat flour, mocaf flour and white sweet potato flour. The treatment of wheat flour: mocaf flour: white sweet potato flour in this study were (200: 0: 0) g, (160:40:0) g and (160: 0: 40) g. The analysis conducted in this study was the organoleptic test using the hedonic test. This study used a completely randomized design. The data obtained were analyzed using ANOVA with advanced DMRT test at the 95\% significance level. The substitution of wheat flour using mocaf flour and white sweet potato flour had an effect on acceptance with the parameters of color, aroma, taste, and texture of white bread. Mocaf flour has the potential to be a substitute for wheat flour in making plain bread compared to sweet potato flour. The taste and texture parameters of mocaf flour bread in the organoleptic test obtained a preference rating from the panelists. While the parameters of taste and texture of sweet potato flour on the organoleptic test received a somewhat favorable assessment from the panelists.
\end{abstract}

Key words : mocaf, bread, substitution, sweet potato, organoleptic test 


\section{PENDAHULUAN}

Roti didefinisikan sebagai makanan yang dibuat dari tepung terigu yang diragikan dengan ragi roti dan dipanggang. Ke dalam adonan boleh ditambahkan garam, gula, susu, lemak dan bahan-bahan pelezat seperti coklat, kismis, selai, dan lain-lain (Rosidah et al., 2019). Di pasaran roti umumnya dijual dalam bentuk roti manis dan roti tawar.

Bahan baku untuk proses pembuatan roti dapat digolongkan menjadi tiga kelompok, yaitu bahan pokok atau bahan utama seperti tepung terigu, ragi dan air, bahan penambah rasa yaitu gula, garam, lemak dalam bentuk shortening /mentega/ margarin, susu dan telur, serta bahan tambahan berupa mineral yeast food (MYF), malt, emulsifier, bahan untuk meningkatkan mutu adonan (dough improver) dan pengawet terutama terhadap jamur (Suryatna, 2015).

Baik roti tawar, roti manis, maupun kue kering bahan dasarnya adalah tepung terigu. Komponen terpenting pada tepung terigu dan tidak terdapat pada bahan tepung lainnya adalah kandungan protein glutenin dan gliadin, yang pada kondisi tertentu dengan air dapat membentuk massa yang elastis dan dapat mengembang yang disebut gluten. Sifat-sifat fisik gluten memungkinkan adonan dapat menahan gas pengembang dan adonan bisa menggelembung. Keadaan ini memungkinkan produk roti berstruktur rongga-rongga yang halus dan seragam serta tekstur yang lembut dan elastis (GuardadoFélix et al., 2020)

Penggunaan tepung singkong yang difermentasi dapat menghasilkan roti dengan nilai glikemiks indeks rendah, tinggi serat dan karakter tekstur roti yang remah (Monthe et al., 2019). Penggunaan tepung ubi jalar putih juga dapat meningkatkan nilai kesehatan produk roti tawar. Ubi jalar merupakan sumber prebiotik dan serat makanan (Rahmawati et al., 2015).

Penelitian sebelumnya mengenai pembuatan roti tawar berbahan dasar tepung mocaf dan ubi jalar dilakukan oleh (Irmawati et al., 2018). Tepung mocaf juga digunakan pada pembuatan roti manis oleh (Yasa et al., 2016). Hal tersebut membuktikan bahwa tepung mocaf dan tepung ubi jalar memang berpotensi dalam pembuatan roti. Perbedaan penelitian Irmawati et al. (2018), dengan penelitian ini yaitu formulasi roti tawar, cara pembuatan roti tawar serta pada penelitian ini uji organoleptik khusus dilakukan pada santriwati pesantren $\mathrm{X}$.

Irmawati et al (2018) menggunakan perbandingan tepung terigu $100 \mathrm{~g}$ : tepung ubi jalar ungu $0 \mathrm{~g}$ : tepung mocaf $0 \mathrm{~g}$ (U0), tepung terigu $65 \mathrm{~g}$ : tepung ubi jalar ungu 30 $\mathrm{g}$ : tepung mocaf $5 \mathrm{~g}$ (U1), tepung terigu 65 $\mathrm{g}$ : tepung ubi jalar ungu $25 \mathrm{~g}$ : tepung mocaf $10 \mathrm{~g}$ (U2), tepung terigu $65 \mathrm{~g}$ : tepung ubi jalar ungu $25 \mathrm{~g}$ : tepung mocaf $10 \mathrm{~g}$ (U3). Pada penelitian ini menggunakan perbandingan tepung terigu:mocaf : ubi jalar putih sebanyak 200:0:0 (g), 160:40:0 (g) dan 160:0:40 (g).

Tujuan penelitian ini adalah untuk mengetahui daya terima roti tawar yang dibuat dengan perbandingan tepung terigu, tepung mocaf dan tepung ubi jalar putih yang berbeda.

\section{BAHAN DAN METODE}

\section{a. Bahan}

Bahan yang digunakan pada penelitian ini yaitu tepung terigu merk Cakra Kembar, tepung mocaf dan tepung ubi jalar putih yang dibeli dari intisari Yogyakarta, susu full cream merk Dancow, gula, margarin merk Blue Band, garam, yeast dan air. Bahan yang digunakan untuk uji organoleptik yaitu borang uji kesukaan dan air mineral. 


\section{b. Alat}

Alat yang digunakan dalam pembuatan roti tawar diantaranya baskom, loyang, kain basah, oven dan lain-lain. Alat yang digunakan untuk uji organoleptic diantaranya cawan untuk tempat sampel, sloki, gelas untuk air mineral.

Prosedur pembuatan roti tawar sebagai berikut:pencampuran bahan kering seperti tepung terigu (sesuai perlakuan), tepung mocaf (sesuai perlakuan), tepung ubi jalar putih (sesuai perlakuan), garam $3 \mathrm{~g}$, gula pasir $12 \mathrm{~g}$ dan yeast $3 \mathrm{~g}$, kemudian pencampuran air hangat $140 \mathrm{ml}$ dengan susu $12 \mathrm{~g}$ dan bahan kering. Tahap selanjutnya adalah pengadukan hingga adonan menjadi kalis, pembentukan bulat dan pengistirahatan adonan selama 30 menit dan ditutup menggunakan kain basah.

Selanjutnya dilakukan pembentukan kotak dengan tebal $3 \mathrm{~cm}$, peletakkan di Loyang, pendiaman selama 30 menit, pemanggangan dengan suhu $170{ }^{\circ} \mathrm{C}$ selama 30 menit. Kemudian roti tawar tersebut dilakukan uji organoleptik.

Perlakuan tepung terigu:tepung mocaf:tepung ubi jalar putih pada penelitian ini yaitu (200:0:0) g, (160:40:0) g dan (160:0:40) g. Sampel dengan perbandingan tepung terigu:tepung mocaf:tepung ubi jalar putih (200:0:0) disebut sebagai S1, sampel dengan perbandingan tepung terigu:tepung mocaf:tepung ubi jalar putih (160:40:0) g disebut sebagai S2, sampel dengan perbandingan tepung terigu:tepung mocaf:tepung ubi jalar putih (160:0:40) g disebut sebagai S3.

\section{c. Pengujian organopletik metode uji hedonik}

Uji hedonik menggunakan 30 panelis agak terlatih. Yaitu santriwati pesantren $\mathrm{X}$ yang merupakan mahasiswa yang telah menempuh mata kuliah mengenai uji sensoris pangan. Uji hedonik dilakukan dengan memberikan 3 macam sampel dan air mineral untuk menetralkan rasa sebelum mencicipi sampel yang berbeda. Para panelis tidak boleh saling berdiskusi saat uji organoleptik berlangsung. Nilai parameter warna, aroma, rasa dan tekstur yaitu $1=$ sangat tidak suka, $2=$ tidak suka, $3=$ agak suka, $4=$ suka dan $5=$ sangat suka.

\section{d. Desain Penelitian}

Penelitian ini menggunakan Rancangan acak lengkap. Data yang diperoleh dianalisis dengan menggunakan ANOVA dengan uji lanjut DMRT pada taraf signifikansi $95 \%$.

\section{HASIL DAN PEMBAHASAN}

Uji sensori atau yang dikenal dengan uji organoleptik sangat penting dilakukan pada produk pangan. Makanan yang bersih, sehat dan bernilai nutrient tinggi namun tidak memiliki rasa yang lezat bisa saja membuat produk tersebut tidak diterima oleh masyarakat. Selera manusia sangat menentukan penerimaan suatu produk. Respon positif oleh indra manusia kepada suatu produk menandakan bahwa produk tersebut memiliki kualitas sensori yang tinggi. Uji sensori dapat digunakan sebagai petunjuk pengembangan produk baru dan optimasi produksi (Breternitz et al., 2017).

Pada uji hedonik, panelis diminta memberi tanggapan pribadi terhadap suatu produk. Penilaian dilakukan dengan memberikan skala hedonik seperti sangat suka, suka, agak suka dan tidak suka (Setyaningsih et al., 2010). Uji kesukaan (hedonik) berdasarkan skor tertentu dapat memberikan gambaran terhadap penerimaan konsumen (Moore et al., 2019).

Warna menjadi parameter pertama yang dinilai oleh konsumen. Warna roti yang cerah akan menarik bagi konsumen. Hasil skor warna uji organoleptik ditunjukkan pada Gambar 1. 


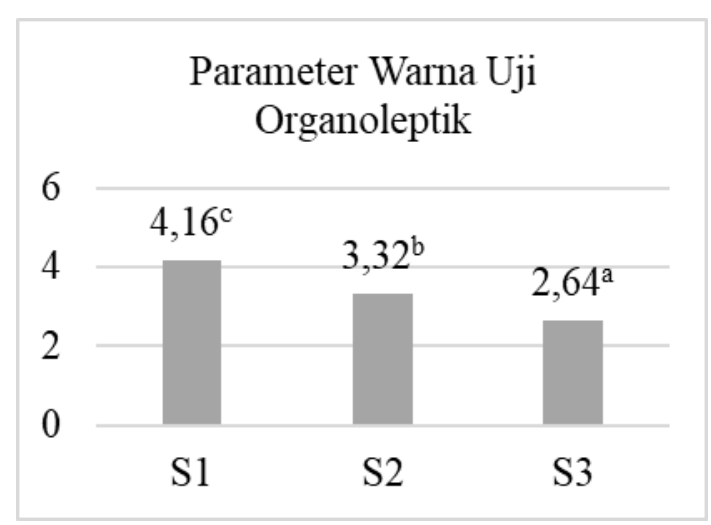

Gambar 1 skor warna uji organoleptik

Pada Gambar 1 menunjukkan bahwa dengan substitusi tepung mocaf dan tepung ubi jalar berpengaruh terhadap penurunan skor parameter warna pada uji organoleptik. Substitusi tersebut dapat menurunkan kecerahan roti tawar. Hal ini dikarenakan tepung mocaf dan tepung ubi jalar memiliki warna yang kurang putih jika diandingkan dengan tepung terigu.

Bahan baku dapat berpengaruh terhadap roti tawar yang dihasilkan. Hasil skor aroma uji organoleptik disajikan pada Gambar 2.

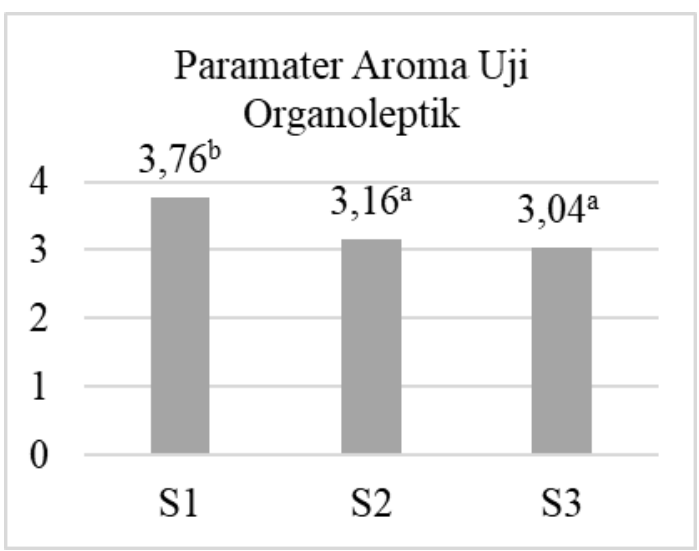

Gambar 2 skor aroma uji organoleptik

Substitusi tepung terigu dengan tepung mocaf dan tepung ubi jalar dapat menurunkan skor aroma produk roti tawar.

Hasil parameter rasa uji organoleptik ditunjukkan pada Gambar 3.

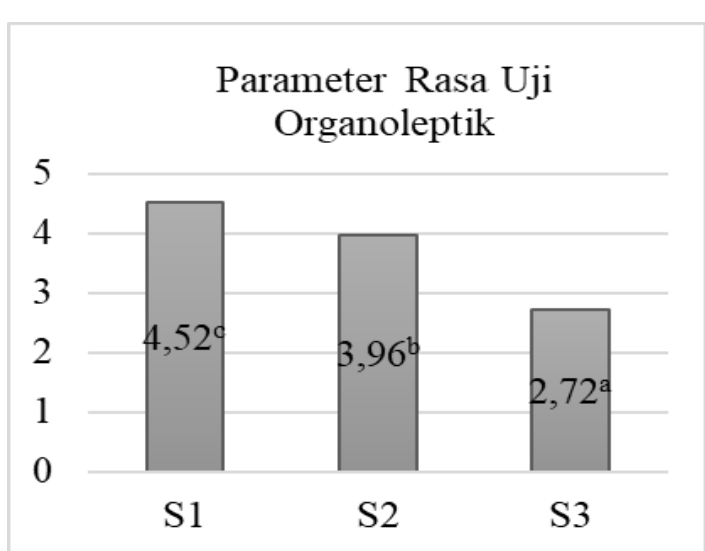

Gambar 3 parameter rasa uji organoleptik

Berdasarkan Gambar 3 diketahui bahwa sampel S1 memiliki skor rasa tertinggi disusul oleh sampel S2 dan nilai kesukaan terendah terdapat pada sampel S3. Gambar 1 menunjukkan bahwa tepung mocaf lebih berpotensi menggantikan tepung terigu dalam pembuatan roti tawar dibandingkan tepung ubi jalar. Roti tawar tepung mocaf memiliki skor 3,96 yang berarti konsumen suka terhadap produk tersebut sedangkan roti tawar ubi jalar memiliki skor 2,72 yang berarti konsumen agak suka terhadap produk tersebut. Nilai tertinggi yaitu pada roti tawar tanpa substitusi sebesar 4,52 yang berarti konsumen sangat suka pada produk tersebut.

Konsumen lebih mengenal tepung terigu dalam pembuatan roti tawar sehingga roti tawar tepung terigu memiliki nilai tertinggi. Rasa dan bau singkong pada tepung mocaf sudah hilang sehingga konsumen memberikan skor suka terhadap produk roti tawar mocaf. Pada pembuatan tepung mocaf terdapat proses fermentasi yang menyebabkan rasa dan aroma khas singkong menjadi hilang (Amanu dan Susanto, 2014). Berbeda halnya dengan tepung ubi jalar, rasa dan aroma ubi jalar masih tetap ada sehingga konsumen memberikan penilaian agak suka terhadap produk roti tawar ubi jalar.

Tekstur seringkali memberikan pengaruh besar terhadap suatu produk, namun jika tekstur bukan merupakan karakteristik 
sensori yang prinsipal dengan kata lain tekstur bukan merupakan karakteristik dominan maka tekstur tidak memberikan pengaruh besar terhadap penerimaan produk (Moore et al., 2019).

Tingkat kesukaan panelis terhadap tekstur roti dipengaruhi oleh kelembutan dari roti (Anggarawati et. al., 2019). Hasil parameter tekstur pada uji organoleptik ditunjukkan pada Gambar 4.

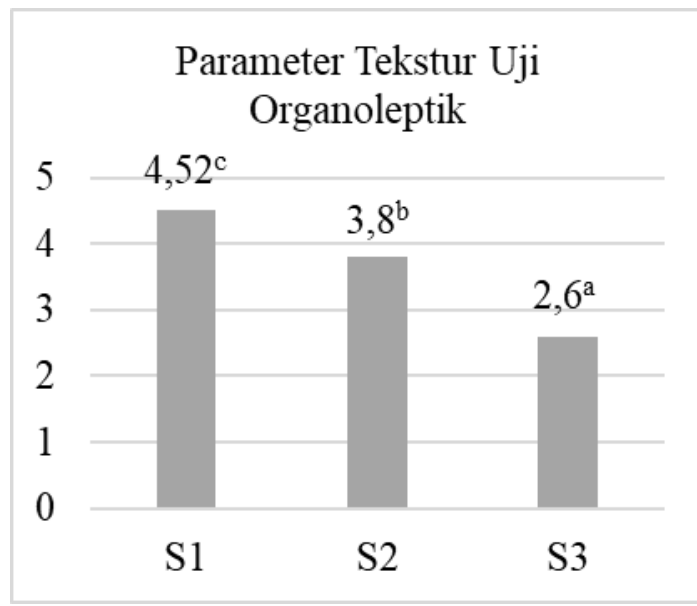

Gambar 4 Hasil parameter tekstur

Produk roti tawar S1 memiliki skor tekstur yang tertinggi (sangat disukai panelis) disusul dengan roti tawar S2 (disukai panelis) dan S3 (agak disukai panelis). Roti tawar S1 terbuat dari tepung terigu tanpa substitusi, dimana tepung terigu mengandung gluten yang dapat menyerap air lebih banyak sehingga berpengaruh terhadap kelembutan, keelastisan roti tawar dan dapat mengembang tinggi (Yasa et al., 2016).

Berdasarkan Pusuma et al. (2018), panelis menyukai roti tawar yang lunak dan elastis. Pada roti tawar S3 yang terbuat dari ubi jalar memiliki skor tekstur terendah dikarenakan teksturnya paling keras dan adonan sedikit mengembang dibanding roti tawar mocaf dan roti tanpa substitusi.

Tekstur roti tawar dipengaruhi oleh adanya kandungan protein, kadar air dan lemak dari bahan baku pembuatan roti. Adanya pori-pori halus pada roti tawar karena udara masuk ke dalam adonan dan terdispersi dalam bentuk gelembunggelembung yang halus ketika pencampuran dan pengulenan tepung dan air, karena dalam tepung terigu mengandung protein yang mampu membentuk gluten ketika ditambah air dan perlakuan mekanis (Nuraini , 2011).

\section{KESIMPULAN}

Substitusi tepung terigu menggunakan tepung mocaf dan tepung ubi jalar putih berpengaruh terhadap daya terima dengan parameter warna, aroma, rasa, dan tekstur roti tawar. Tepung mocaf berpotensi sebagai pengganti tepung terigu dalam pembuatan roti tawar dibandingkan tepung ubi jalar.

Parameter rasa dan tekstur roti tawar tepung mocaf pada uji organoleptik mendapatkan penilaian suka dari panelis. Sedangkan parameter rasa dan tekstur roti tawar tepung ubi jalar pada uji organoleptik mendapatkan penilaian agak suka dari panelis.

\section{UCAPAN TERIMAKASIH}

Ucapan terimakasih kepada Santriwati Pondok Pesantren $\mathrm{X}$ yang bersedia menjadi panelis dalam penelitian ini.

\section{DAFTAR PUSTAKA}

Amanu, F.N. dan Susanto, W.H. 2014. Pembuatan tepung mocaf di Madura (kajian varietas dan lokasi penanaman) terhadap mutu dan rendemen. Jurnal Pangan dan Agroindustri 2 (3):161-169.

Anggarawati, N.K.A., Ekawati, I.G.A. Wiadnyani, A.A.I.S. pengaruh substitusi tepung ubi jalar ungu termodifikasi (Ipomoea Batatas var. 
Ayamurasaki) terhadap karakteristik waffle. Jurnal Ilmu dan Teknologi Pangan 8 (2):160-170.

Breternitz, N.R., Bolini, H.M.A, Hubinger, M.D. 2017. Sensory acceptance evaluation of a new food flavoring produced bymicroencapsulation of a mussel (Perna perna) protein hydrolysate. LWT-Food Science and Technology 83: 141-149.

Guardado-Félixa, D., Lazo-Vélezb, M.A., Pérez-Carrilloa, E., Panata-Saquicilib, D.E., Serna-Saldívara, S.E. 2020. Effect of partial replacement of wheat flour with sprouted chickpea flours with or without selenium on physicochemical, sensory, antioxidant and protein quality of yeast-leavened breads. LWT-Food Science and Technology $129 \quad$ (109517). https://doi.org/10.1016/j.lwt.2020.109 517

Irmawati, Ansharullah, Baco, A.R. 2018. Pengaruh formulasi roti tawar berbasis mocaf dan ubi jalar ungu (ipomoea batatas. L) terhadap nilai proksimat dan aktivitas antioksidan. J. Sains dan Teknologi Pangan 3(2)

Moore,C.J; Lindke, A.B.S; Cox, G.O. 2019. Research article using sensory science to evaluate consumer acceptance of recipes in a nutrition education intervention for limited resource populations. Journal of Nutrition Education and Behavior. https://doi.org/10.1016/j.jneb.2019.07. 012

Monthe, O.C., Grosmaireb, L., Nguimboua, R.M., Dahdouhb, L., Riccib, J., Tranc,T., Ndjouenkeu, R. 2019. Rheological and textural properties of gluten-free doughs and breads based on fermented cassava, sweet potato and sorghum mixed flours. LWTFood Science and Technology 101:575-582.
Nuraini, A. 2011. Aplikasi millet (Pennisetum Spp) merah dan millet kuning sebagai substitusi terigu dalam pembuatan roti tawar: evaluasi sifat sensoris dan fisikokimia". Skripsi. Universitas Sebelas Maret, Surakarta.

Pusuma, D.A. Yhulia Praptiningsih, Y. Choiron, M. 2018. Karakteristik roti tawar kaya serat yang disubstitusi menggunakan tepung ampas kelapa. Jurnal Agroteknologi 12(1).

Rahmawati, A., Supartono dan Edy Cahyono. 2015. Kandungan Kimia dan Potensi Beberapa Jenis Tepung Ubi Jalar pada Pembuatan Roti. Indo. J. Chem. Sci. 4 (1)

Rosidah, Agustina, T., Paramita, O. 2019. Kualitas organoleptik roti manis subtitusi tepung jagung kuning dengan metode penepungan berbeda. Teknobuga 7 (1).

Setyaningsih, D., Apriyantono, A., Sari, M.P. 2010. Analisis Sensoris untuk Industri Pangan dan Agro. Bogor: IPB Press.

Suryatna, B.S. 2015. Peningkatan Kelembutan Tekstur Roti Melalui fortifikasi Rumput Lauteuchema Cottoni. Teknobuga 2 (2).

Yasa, I.W.S, Zainuri, Zaini, M.A., Hadi, T. 2016. Mutu roti berbahan dasar mocaf: formulasi dan pembuatan adonan. Pro Food (Jurnal Ilmu dan Teknologi Pangan) 2 (2). 